\title{
İlkokul Çocukları İçin Bir Mola Mı?: Teneffüs Gerçeği
}

\author{
Özlem APAK TEZCAN ${ }^{1}$
}

İlkokul çocuklarının zamanlarının büyük bir kısmını geçirdikleri bir ortam olan okulda; farklı çevrelerden gelen birçok yasıtıyla sosyallestikleri teneffüsler de dersler kadar önemli bir ortam sunmaktadır. Bu doğrultuda çalısmanın amacı, ögrencilerin ve öğretmenlerin teneffüse yönelik görüşlerini alarak var olan durumu ortaya koymaktır. Araştırma nitel araştırma desenlerinden biri olan durum çalışması deseninde kurgulanmıştır. Araştırmanın çalışma grubunu 2017/18 öğretim yılında İstanbul' da bulunan 3 farklı okulda okuyan ve 3. sınıfta öğrenim gören 125 öğrenci ve 5 öğretmen oluşturmaktadır. Elde edilen veriler içerik analizi ile çözümlenmiştir. Çalısma sonucunda öğrenciler teneffüslerini çoğunlukla açık alanda oyun oynayarak ve spor yaparak geçirdiklerini, diğer öğrencilerin kendilerine çarpması/itmesinden ve gürültüden rahatsız olduklarını ifade ettikleri görülmektedir. Hayallerindeki teneffüslere yönelik olarak ise en çok okuldaki fiziki alanların ve zamansal düzenlemelere yönelik fikirleri kapsadığı görülmektedir. Öğretmenlerin teneffüslerin daha etkili ve verimli geçmesine yönelik görselleri incelendiğinde ise okuldaki fiziki altyapıya ilişkin problemlerin düzeltilmesine yönelik yapılması gereken değişikliklere vurgu yaptıkları görülmektedir.

İlkokul
İlkokul öğrencisi
Sınıf öğretmeni
Teneffüs
Makale Hakkında
Geliş Tarihi: 24.01.2019
Kabul Tarihi: 29.09.2020

\section{Is It a Break for Primary School Children?: The Fact about Recess}

\begin{abstract}
In the school environment where they become acquainted with rules and acquire certain knowledge, attitudes, skills, and behaviors, recesses during which they socialize with a lot of peers coming from different backgrounds and learn social skills and values are as important as classes. In this regard, this study aims to reveal students' and teachers' views about recesses. The study employs the case study method a qualitative research design. The sizes or features of school gardens were considered while determining the study group. 125 third graders from three different selected schools and five teachers from each school constituted the study group. Data were collected through student and teacher form prepared by the researcher and analyzed through content analysis. At the end of the study, an attempt was made to show student and teacher views concerning the steps that can be taken to make recesses more effective and productive.
\end{abstract}

Keywords

Primary school

Primary school students

Primary school teacher

Recess

About Article

Received: 24.01.2019

Accepted: 29.09.2020

Doi: 10.18026/cbayarsos.517173

\footnotetext{
1 İletişim Yazarı: ozlemapak@kocaeli.edu.tr
} 


\section{Giriş}

Aile ve toplumun sosyal yapısı içindeki ekonomik gerçekler, güvenlik sorunları, kentsel fiziki imkanların sınırlı olması ve sanal iletişim teknolojilerinin artmasıla birlikte çocukların enerjilerini atabilecekleri zaman ve mekânlar azalmıştır (Bumin, 2018). Bu durum günün büyük bir bölümünü okulda geçiren çocuklar için temel gereksinimlerini karşılayabilecekleri, oyun oynayarak farklı etkinlikler gerçekleştirecekleri şekilde düzenlenen okullara olan ihtiyacı da beraberinde getirmektedir (Kıncal ve Genç, 2002).

Çocukların ihtiyaçlarını karşılayabilecekleri teneffüsler, çocukların dişarı çıkmak, enerjilerini boşaltmak ve arkadaşlarıyla oyun oynadıkları zaman dilimi olarak tanımlanabilir (Tekeci, 2018). Aynı zamanda oyun kurma, organize etme, akranları ile sosyalleşme ve doğayı keşfetme fırsatı buldukları, okul gününün ayrılmaz bir parçası olarak da tanımlanmaktadır (Stapp ve Karr, 2018). Teneffüs kelimesi ayrıca okulda geçirilen zamanın (yarı zamanlı ya da tam zamanlı okullar) miktarı \%15-25'i arasındadır (Baltcford ve Sumpner, 1998; Zask ve ark., 2001). Bu nedenle teneffüsler çocukların fiziksel aktivitelerin sağlamaları açısından önemli bir rol oynamaktadır.

Teneffüslerin yukarıda belirtilen ihtiyaçların karşılamasının ötesinde çocukların bilişsel, duygusal, fiziksel ve sosyal yönden gelişimlerine katkı sağladığı da ortaya konulmaktadır (Ramstetter, Murray ve Garner, 2010; Brez ve Sheets, 2017). Bu anlamda teneffüsleri, sadece fiziksel aktivite yapılan bir mola olarak düşünmemek gerekmektedir. “Teneffüsler yapılandırılmalı mı yapılandırılmamalı mı?" sorusu gündeme gelmektedir. Bazı araştırmacılar yapılandırılmaması gerektiğini, çocuğun kendi ihtiyacına göre karar vermesi gerektiğini savunurken, bazı araştırmacılar yapılandırılması gerektiğini, çünkü çocuğun kendi ihtiyaçlarını belirleme noktasında yetersiz kalacağını ileri sürmektedir (Rhea, 2016). Teneffüslerin nasıl geçirilmesi gerektiğine yönelik süreç hakkında farklı görüşler olsa da "kaliteli" zaman geçirmelerine olanak sağlayan bir zaman dilimi ve uygun ortam yaratılmasının önemi vurgulanmaktadır.

Çocuklar için teneffüsler; oyun oynayabildikleri, arkadaşlarıyla buluşabildikleri, yetişkinlerin kontrolü olmadan sosyal beceri ve yeterliliklerini geliştirebildikleri bir ortam olması bakımından da büyük önem taşımaktadır (Rhea, 2016). Bu anlamda temel eğitimin amaçladığ hedefleri kazanmaları açısından da eğitsel bir öneme sahip olduğu düşünülebilir. Örneğin, ortak alanı birlikte kullanma, arkadaşlarına saygılı olma, zamanını yönetme, öz disiplin geliştirebilme vb. gibi birçok sosyal beceriyi öğrenme ve uygulama fırsatı yakalama şansı verir. Genel olarak teneffüslerin yararları şöyle sıralanabilir (Ramstettler, Murray ve Garner, 2010):

a. Çocukların fiziksel becerilerini geliştirmeye yardımcı olur.

b. Diğer çocuklara etkileşim fırsatı yaratması sebebiyle sosyal beceri gelişimine katkıda bulunur.

c. Oyun oynamak ya da sadece sessiz bir ortamda dinlenmek entelektüel kapasiteyi artırır.

d. Diğer çocuklarla bir arada olmak, ahlaki bilinç kazanmalarına katkı sağlar.

e. Daha iyi "sınıf içi davranış" sergilemelerini sağlar.

Bu bağlamda çocukların teneffüs süresince yapılandırılmış oyunlar oynaması sağlanırsa sınıfa geri dönme zamanı geldiğinde öğrenmeye hazır olarak gelebileceklerini ifade etmişlerdir. 
(London ve diğerleri, 2015). Pellegrini ve Davis (1993) tarafından yapılan çalışmada da ilkokul çocukları için teneffüsler geciktiğinde ya da ertelendiğinde dikkatlerinin dağıldığı ve teneffüse çıktıklarında normalden daha hareketli olduklarını ortaya koymuşlardır. Pozitif okul iklimi; okulda fiziksel ve duygusal güvenlik sağlama, akranlarla ve yetişkinlerle olumlu ilişkiler kurma; öğrenmeyi destekleme ve teşvik etme sorumluluklarını yerine getiren kurumsal ortam olarak tanımlanabilir (Golinkoff, Hirsh-Pasek ve Singer, 2006; London ve diğerleri, 2015). Bu açıdan bakıldığında da teneffüsleri pozitif okul ikliminin bir parçası olarak görmek kaçınılmazdır.

Aynı zamanda öğrencilerin dinlenmesi için ayrılan bir zaman dilimi olarak da tanımlanan teneffüsler gürültünün de en yüksek seviyelere çıktığı anlar olarak da tanımlanabilir. Bu yönüyle de hem öğrenciler hem de okullarda görev alan eğiticiler için hem de okulda görev alan eğiticiler için en önemli problemlerden biri olarak karşımıza çıkmaktadır (Tamer, Küçükçiftçi ve Şan, 2011). İlkokullardaki gürültünün sebepleri olarak öğrencilerin oynarken ve teneffüse çıkarken koşuşturmaları ve sosyal olanakların eksikliğinden dolayı daha fazla gürültü çıkarma eğilimlerine bağlanmaktadır (Bulunuz ve diğ, 2018). Bu durumun öğrencilerin sınıf içerisinde oyun ihtiyacını yeterince karşılayamadığı, yeterince hareket edemediği ve daha çok pasif konumda olmasından kaynaklandığı da söylenebilir.

Birleşmiş Milletler Çocuk Bildirgesi de, çocuk hakları içinde oyun oynama hakkı olduğunu kabul etmektedirler (London ve diğerleri, 2015). Özellikle sosyo ekonomik yapısı daha düşük olan bölgelerde çocukların hem ruhsal hem de fiziksel gelişimlerinin hayati bir parçası olarak "oyun" u gördükleri de birçok araştırma ile ortaya konmaktadır. Örneğin Amerikan Pediatri Akademisi (APA) okulların pozitif teneffüs programları geliştirmeleri için bir takım kurallar belirlemişlerdir. Bu kurallarla farklı eyaletlerde (teneffüs sayısını veya sürelerini azaltma vb) yapılabilecek uygulamaları belli bir standarda bağlamışlardır. Bu uygulamalara örnek olarak yapılan bir araştırmaya göre, 6 düşük gelirli ilkokulda, herhangi bir kar amacı gütmeyen bir organizasyon tarafından güvenli, sağlıklı ve kapsayıcı bir ortamı teşvik eden teneffüs bazlı bir program geliştirildi. Bu çalışmada eğitimli, tam-zamanlı "koçlar" teneffüsü geliştirmek hedefiyle çalışmanın yürütüldügü okula gönderildi ve belirlenen ortak kurallar kapsamında, çatışmaları çözme araçları sunan ve pozitif dili ve kapsayıcı davranışı teşvik eden teneffüs oyunları oluşturmak için öğrencilerle birlikte çalışıldı (London ve ark., 2015).

Teneffüs, öğrencilerin yaşadıkları deneyimlerin yanında zaman ve mekân olarak da eğitim/öğretimin önemli bir bölümüdür (Yaman, 2006). Bu bağlamda teneffüsler, bazı sınırlandırılmalar olsa da de çocukların akranları ile oyun oynayabildikleri tek zaman dilimi gibi görülmektedir (Factor, 2004). Yine okula duyulan ilginin artması, ve öğrencilerin fiziksel, estetik ve sosyal memnuniyet düzeylerinin artırılabilmesi için de teneffüslerin önemi büyüktür (Karasel Ayda ve Güneyli, 2018). Bu gerçekten hareketle araştırmanın amacı, ilkokullarda teneffüse ilişkin öğrenci ve öğretmen görüşlerini saptamaktır. Bu amacı gerçekleştirmek için aşağıdaki sorulara cevap aranmıştır.

a. Öğrenciler teneffüste vakitlerini nasıl geçirmektedir?

b. Teneffüslerde öğrencileri en çok rahatsız eden durumlar nelerdir?

c. Öğrencilerin hayallerindeki teneffüslere yönelik fikirleri nelerdir?

d. Öğretmenlerin daha etkili ve verimli teneffüsler geçirilebilmesine yönelik fikirleri nelerdir? 


\section{Yöntem}

\section{Araştırma Deseni}

$\mathrm{Bu}$ araştırma nitel araştırma desenlerinden biri olan durum çalışması türlerinden "tanımlayıcı durum çalışması" desenine uygun olarak kurgulanmıştır. Durum çalışmasında karmaşık bir sosyal olgunun anlaşılması arzusuna dayanmaktadır (Yin, 2003). Ayrıca araştırmacının "neden" ve "nasıl" sorularıyla sosyal olguyu derinlemesine açıklamaya çalıştığı durumlar için uygundur. Bir kişi, sosyal bir ortam, bir olay ya da bir grupla ilgili durumun işlevinin nasıl gerçekleştiğinin etkili bir şekilde anlaşılabilmesini sağlayan sistemli bir veri toplama süreci olarak da tanımlanabilir (Berg, 2001; Yıldırım ve Şimşek, 2008). Tanımlayıcı durum çalışmaları ise betimseldir; araştırmacılar bir durumun hakkında bilgi vermek için bir ya da iki durum kullanirlar (Davey, 2009).

\section{Çalışma Grubu}

Araştırmanın çalışma grubunu 2017-2018 öğretim yılı birinci döneminde İstanbul ili Anadolu yakasında bulunan 2 kamu 1 özel ilkokulda öğrenim gören 125 öğrenci ve 15 öğretmen oluşturmuştur. Araştırmanın çalışma grubu amaçlı örnekleme yöntemlerinden biri olan ölçüt örnekleme yolu ile belirlenmiştir. Amaçlı örnekleme, araştırılan konu üzerinde detaylı bilgiye sahip olduğu düşünülen durumların derinlemesine çalışılmasına fırsat vermektedir (Patton, 1997). Ölçüt örnekleme yöntemindeki temel anlayış ise önceden belirlenmiş bir takım ölçütü karşılayan durumları çalışma fırsatı sunmasıdır (Yıldırım ve Şimşek, 2008). Çalışma grubunun seçiminde kullanılan ölçütler; a) Öğretmenlerin gönüllü olması, b) öğretmenlerin ilkokullarda 1-4. Sınıfların tümünde öğretmenlik deneyiminin olması, c) Okul bahçelerinin yapısal olarak bir takım farklılıkları olması gibi ölçütler göz önüne alınmıştır.

\section{Verilerin Toplanması}

Veriler, arastırmacı tarafından hazırlanan ögrenci formu (açık uçlu 3 sorudan olusan bir form) ve ögretmen formu (kapalı uçlu 6 soru ve açık uçlu 1 sorudan olusan form) ile toplanmıştır.

Öğrenci Formu: Araştırmacı tarafından hazırlana bu form 3 açık uçlu sorudan oluşmaktadır. Teneffüse ilişkin öğrenci algılarını-deneyimlerini ve ne gibi düzenlemeler yapılması gerektiğini düşündüklerini öğrenmek amacıyla ilkokul 3. sınıf öğrencisine uygulanmak üzere hazırlanmıştır. Hazırlanan form, uzman görüşüne sunulmuş, 3 alan uzmanının (Sınıf öğretmenliği, Rehb. ve Psik. Dan ve Eğitim Yön. Tef. Plan. ve Eko.) görüşleri alınmış, gerekli düzenlemeler yapılmıştır.

Öğretmen Formu: Araştırmacı tarafından hazırlanan bu form, öğretmenlerin görev yaptıkları okulun fiziki özelliklerini betimlemeleri ve daha etkili ve verimli teneffüslere yönelik fikirlerini sunmaları istenmiştir. Bu doğrultuda 6 kapalı uçlu 1 de açık uçlu sorudan toplam 7 soruluk form alan uzmanlarına sunulmuş, 2 alan uzmanının (Sınıf Öğretmenliği ve Eğitim Yön. Tef. Plan. ve Eko.) görüşleri alınmış, gerekli düzenlemeler yapılmıştır.

\section{Verilerin Analizi}

Elde edilen veriler içerik analizi ile çözümlenmiştir. Uygulamadan elde edilen formlar Microsoft Excel programına doğrudan aktarılarak numaralandırılmıştır. Daha sonra geçersiz olan formlar araştırma dişında tutularak elde kalan formlar üzerinde araştırma soruları (tema) 
altında alt temalara ve kodlara ulaşılmıştır. Yapılan analizde frekans ve yüzde değerleri verilmiş, ilgili araştırma sorusu (tema) altında çalışma grubundan elde edilen cevaplar, doğrudan alıntılama yoluyla analiz tablosu altında örneklendirilmiştir. Okullar A, B ve C; öğrenciler Ö1, Ö, Ö3...; öğretmenler ise ÖĞR1, ÖĞR 2.. şeklinde kodlanarak metin içerisinde yer verilmiştir.

Analizlerde kodlayıcılar arası güvenilirliği hesaplamak için Miles ve Huberman (1994) formülünden yararlanılmıştır. Araştırmacı dışındaki kodlayıcı, Sınıf Öğretmenliği alanında doktorasını tamamlamış, Hayat Bilgisi ve Sosyal Bilgiler Öğretimi konusunda çalışmaları olan ve nitel araştırmalar yapan bir akademisyen tarafından daha yapılmıştır. Bu çalışmada kodlayıcılar arası güvenirlik ise \%92 olarak hesaplanmıştır. Ayrıca öğrenci ve öğretmen görüşleri kendi 1 yazıları ile metin içerisine yansıtılarak inandırıcılığı sağlanmaya çalışılmıştır.

\section{Bulgular}

Bu bölümde araştırma soruların yönelik olarak elde edilen öğrenci ve öğretmen görüşleri ilgili araştırma sorusu altında belirtilmiştir.

\section{TEMA I: Öğrencilerin Teneffüsteki Ortamlar ve Eylemleri}

Öğrencilere sorulan "teneffüslerde vakitlerini nasıl geçiriyorsun?" sorusuna ilişkin görüşleri Tablo 1'de tema, alt tema ve kodlar şeklinde yer almaktadır.

Tablo 1. Öğrencilerin teneffüste vakitlerini geçirdikleri ortam ve eylemler

\begin{tabular}{|c|c|c|c|c|c|}
\hline \multirow{3}{*}{ Alt Temalar } & \multirow{3}{*}{ Kodlar } & \multirow{3}{*}{ f } & \multirow{3}{*}{$\%$} & \multicolumn{2}{|c|}{ Toplam } \\
\hline & & & & & \\
\hline & & & & f & $\%$ \\
\hline \multirow{8}{*}{$\begin{array}{l}\text { Ö̈̆grencilerin } \\
\text { teneffüste açık } \\
\text { alandaki } \\
\text { eylemleri }\end{array}$} & Bahçede oyun oynuyorum. & 90 & 49 & \multirow{8}{*}{181} & \multirow{8}{*}{7} \\
\hline & Top ile oynuyorum (basketbol, futbol vb.). & 40 & 22 & & \\
\hline & Bahçede sohbet ediyorum & 14 & 8 & & \\
\hline & Koşuyorum. & 12 & 7 & & \\
\hline & Kantine gidiyorum. & 12 & 7 & & \\
\hline & Arkadaşlarımla dolaşıyorum. & 9 & 5 & & \\
\hline & Dışarı çıkıp hava alıyorum. & 2 & 1 & & \\
\hline & Yaralanan arkadaşlarıma yardım ediyorum. & 2 & 1 & & \\
\hline \multirow{6}{*}{$\begin{array}{l}\text { Öğrencilerin } \\
\text { teneffüste } \\
\text { kapalı } \\
\text { alandaki } \\
\text { eylemleri }\end{array}$} & Kitap okuyorum. & 19 & 25 & \multirow{6}{*}{75} & \multirow{6}{*}{29} \\
\hline & Satranç oynuyorum. & 12 & 16 & & \\
\hline & Oyun oynuyorum (adam asmaca, isim şehir vb.). & 8 & 11 & & \\
\hline & Sınıfta vakit geçiriyorum. & 8 & 11 & & \\
\hline & Resim yapıyorum. & 6 & 7 & & \\
\hline & Tuvalete gidiyorum. & 6 & 7 & & \\
\hline
\end{tabular}


Ders çalışıorum. $\quad \begin{array}{lll}6 & 7\end{array}$

Dinleniyorum. $\quad 2 \quad 3$

Camdan dişarıyı izliyorum. $\quad 2 \quad 3$

Atıştırmalıklarımı yiyorum. $\quad 2 \quad 3$

Arkadaşlarımı kızdırıyorum /sataşıyorum. $\quad 2 \quad 3$

Kütüphaneye gidiyorum. $\quad 1 \quad 2$

Dans ediyorum. $\quad \begin{array}{lll}1 & 2\end{array}$

Genel Toplam $256 \quad 100 \quad 256 \quad 100$

Tablo 1 incelendiğinde öğrencilerin ağırlıklı olarak açık alanda okul bahçesinde oyun oynayarak, top oynayarak veya koşturarak geçirdikleri söylenebilir. Kapalı alan tercih eden öğrenciler ise daha çok sınıfta, kitap okuyarak, satranç oynayarak ve kalem-kâğıt oyunları oynayarak geçirdikleri söylenebilir. Öğrenci cevaplarından bazıları şu şekildedir:

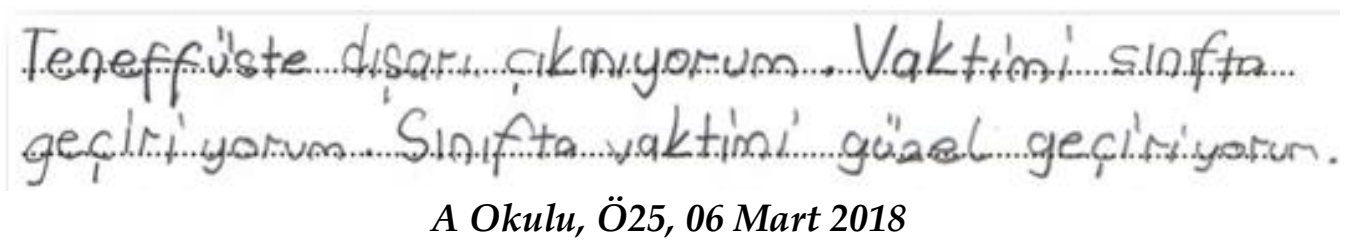

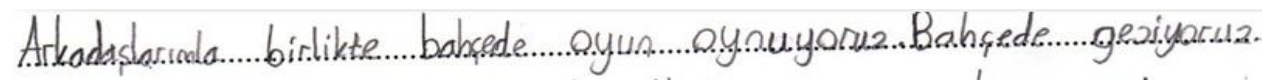

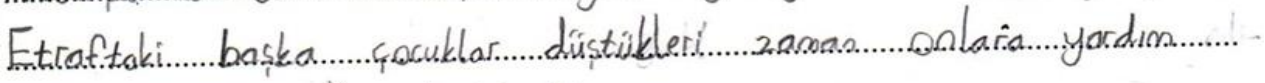

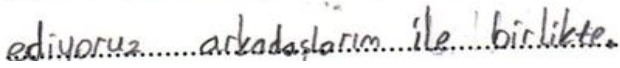

B Okulu, Ö 2, 08 Mart 2018

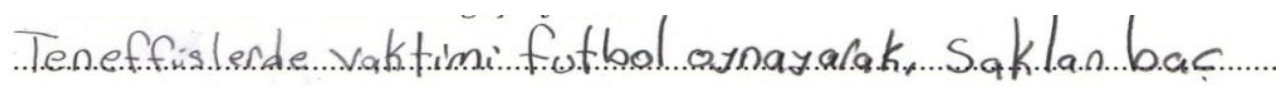

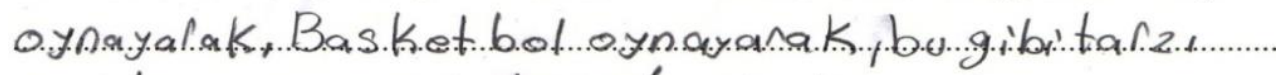

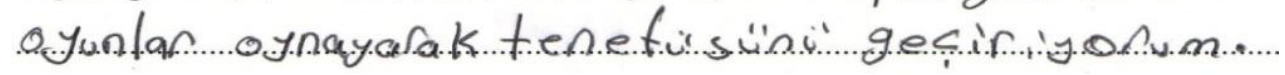

C Okulu, Ö 16, 09 Mart 2018

TEMA II: Teneffüslerde öğrencileri en çok rahatsız eden durumlar

Öğrencilere sorulan "Teneffüslerde seni en çok rahatsız eden durumlar nelerdir?" sorusuna ilişkin görüşleri Tablo 2'de tema, alt tema ve kodlar şeklinde yer almaktadır. 
Tablo 2. Öğrencilerin teneffüste vakitlerini geçirdikleri ortam ve eylemler

\begin{tabular}{|c|c|c|c|c|c|}
\hline \multirow{2}{*}{ Alt Temalar } & \multirow{2}{*}{ Kodlar } & \multirow{2}{*}{$f$} & \multirow{2}{*}{$\%$} & \multicolumn{2}{|c|}{ Toplam } \\
\hline & & & & $f$ & $\%$ \\
\hline \multirow{10}{*}{ Öğrenciler } & Başka öğrencilerin bana çarpmasi/itmesi & 51 & 36 & \multirow{10}{*}{143} & \multirow{10}{*}{71} \\
\hline & Çok gürültü yapılması & 25 & 17 & & \\
\hline & Kavga edilmesi & 20 & 14 & & \\
\hline & Oyuna alınmama & 10 & 7 & & \\
\hline & Oyunumun bozulması & 9 & 6 & & \\
\hline & Alay edilmesi & 9 & 6 & & \\
\hline & Koridorda koşulması & 7 & 5 & & \\
\hline & Kötü söz/küfür edilmesi & 5 & 4 & & \\
\hline & Oyunda mızıkçılık yapılması & 4 & 3 & & \\
\hline & Tükürülmesi & 3 & 12 & & \\
\hline \multirow{3}{*}{ Okul } & Teneffüsün çabuk bitmesi & 42 & 79 & \multirow{3}{*}{53} & \multirow{3}{*}{26} \\
\hline & Bahçenin çok kalabalık olması & 8 & 15 & & \\
\hline & Bahçenin küçük olması & 3 & 6 & & \\
\hline \multirow[t]{2}{*}{ Öğretmenler } & Yağmur/kar yağınca bahçeye çıkmanın yasaklanması & 3 & 60 & \multirow[t]{2}{*}{5} & \multirow[t]{2}{*}{3} \\
\hline & Nöbetçi öğretmenin sürekli bağırması & 2 & 40 & & \\
\hline
\end{tabular}

Tablo 2 incelendiğinde öğrencileri rahatsız eden durumlar, öğrenci, okul ve öğretmen alt temalarına ayrılmıştır. En çok diğer öğrencilerin yaptığı davranışlardan rahatsızlık oldukları, okul alt temasında teneffüsün çabuk bitmesinden duydukları rahatsızlığ 1 dile getirdikleri görülmektedir. Öğrenci cevaplarından bazıları şu şekildedir:

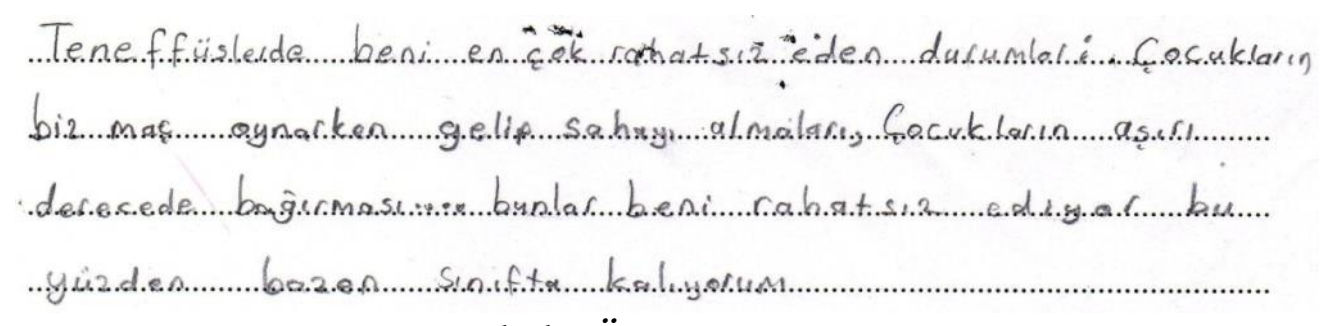

A Okulu, Ö 18, 03 Mart 2018 


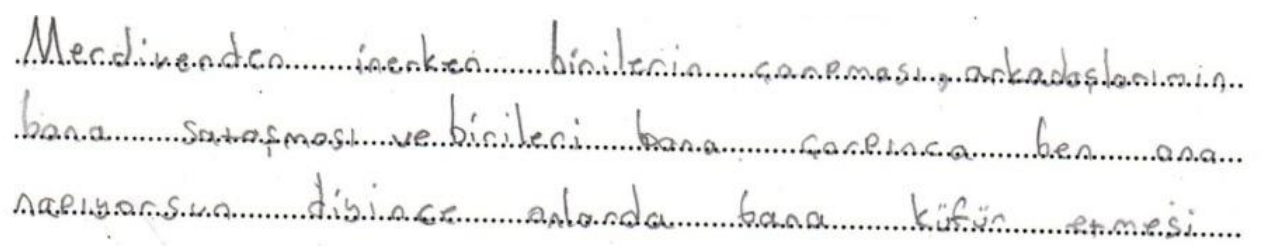

B Okulu Ö 30, 08 Mart 2018

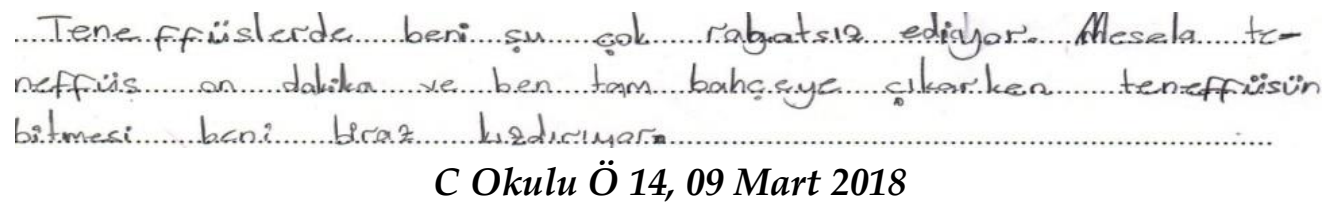

TEMA III: Öğrencilerin teneffüse yönelik düzenleme önerileri

"Sence teneffüsleri daha güzel geçirebilmek için ne gibi düzenlemeler yapılabilir?" sorusuna ilişkin görüşleri Tablo 3' de tema, alt tema ve kodlar şeklinde yer almaktadır.

Tablo 3. Öğrencilerin teneffüse yönelik düzenleme önerileri

\begin{tabular}{|c|c|c|c|c|c|}
\hline \multirow{2}{*}{ Alt Temalar } & \multirow{2}{*}{ Kodlar } & \multirow{2}{*}{$f$} & \multirow{2}{*}{$\%$} & \multicolumn{2}{|c|}{ Toplam } \\
\hline & & & & $f$ & $\%$ \\
\hline \multirow{13}{*}{$\begin{array}{l}\text { Oyun alanının } \\
\text { fiziksel } \\
\text { düzenlenmesi }\end{array}$} & Park olmalı & 31 & 30 & \multirow{13}{*}{102} & \multirow{13}{*}{46} \\
\hline & Spor alanları olmalı & 23 & 22 & & \\
\hline & Farklı oyun alanları olmalı & 9 & 9 & & \\
\hline & Bahçe büyütülmeli & 7 & 7 & & \\
\hline & Sessiz alanlar olmalı & 6 & 6 & & \\
\hline & Okul duvarları eğlenceli olmalı & 5 & 5 & & \\
\hline & Dinlenme alanları olmalı & 5 & 5 & & \\
\hline & Tırmanma alanları olmalı & 4 & 4 & & \\
\hline & Yere seksek çizilmeli & 3 & 3 & & \\
\hline & Masa tenisi olmalı & 3 & 3 & & \\
\hline & Top havuzu olmalı & 2 & 2 & & \\
\hline & Hikaye okuma alanları olmalı & 2 & 2 & & \\
\hline & Kapılar büyütülmeli & 2 & 2 & & \\
\hline \multirow{5}{*}{$\begin{array}{c}\text { Zamansal } \\
\text { düzenleme }\end{array}$} & Teneffüsler uzatılmalı & 40 & 58 & \multirow{5}{*}{69} & \multirow{5}{*}{32} \\
\hline & Her sinıfa yetecek alan olmalı & 10 & 14 & & \\
\hline & Nöbetçi öğretmen sayısı arttırılmalı & 9 & 13 & & \\
\hline & Teneffüsler planlanmalı & 7 & 10 & & \\
\hline & Okul malzemeleri özgürce kullanılmalı & 3 & 5 & & \\
\hline
\end{tabular}




\begin{tabular}{|c|c|c|c|c|c|}
\hline \multirow{5}{*}{$\begin{array}{l}\text { Oyun alanlarının } \\
\text { çevresel } \\
\text { düzenlenmesi }\end{array}$} & Bahçe zemini çimen olmalı & 11 & 35 & \multirow{5}{*}{32} & \multirow{5}{*}{15} \\
\hline & Ağaç ve çiçek dikilmeli & 16 & 50 & & \\
\hline & Hayvanlar olmalı & 2 & 6 & & \\
\hline & Okul servisleri bahçede beklememeli & 2 & 6 & & \\
\hline & Bahçe hava koşullarına uygun olmalı & 1 & 3 & & \\
\hline \multirow{7}{*}{$\begin{array}{l}\text { Oyun alanlarının } \\
\text { içeriksel olarak } \\
\text { düzenlenmesi }\end{array}$} & Yarışmalar düzenlenmeli & 4 & 28 & \multirow{6}{*}{15} & \multirow{6}{*}{7} \\
\hline & Bazı deneyler bahçede yapılmalı & 3 & 20 & & \\
\hline & Eğitici etkinlikler olmalı & 2 & 13 & & \\
\hline & Müzik çalmalı & 2 & 13 & & \\
\hline & Zeka oyunları oynanmalı & 2 & 13 & & \\
\hline & Öğretmenler de oyuna katılmalı & 2 & 13 & & \\
\hline & Genel TC & 218 & 100 & 218 & 100 \\
\hline
\end{tabular}

Tablo 3 incelendiğinde oyun alanlarının fiziksel düzenlenmesi, zamansal düzenlemeler, oyun alanlarının çevresel düzenlenmesi ve içeriksel düzenlenmesi olmak üzere dört alt tema altında toplandığı görülmektedir. Öğrencilerin ağırlıklı olarak oyun bahçelerinin fiziksel olarak düzenlenmesi (park ve spor alanlarının olması) zamansal düzenlemelerde ise teneffüslerin süresinin uzatılması görüşlerinin ön plana çıtığı söylenebilir. Öğrenci cevaplarından bazıları şu şekildedir:

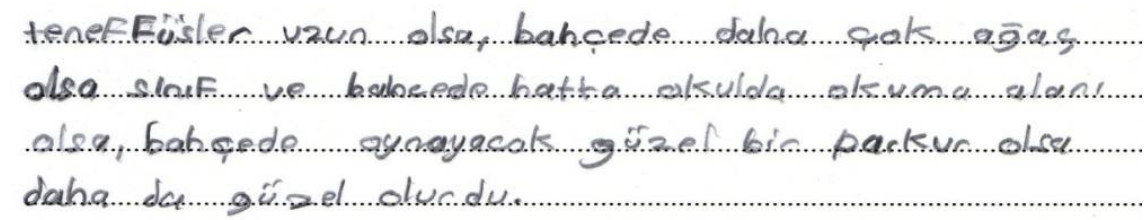

A Okulu Ö34, 06 Mart 2018

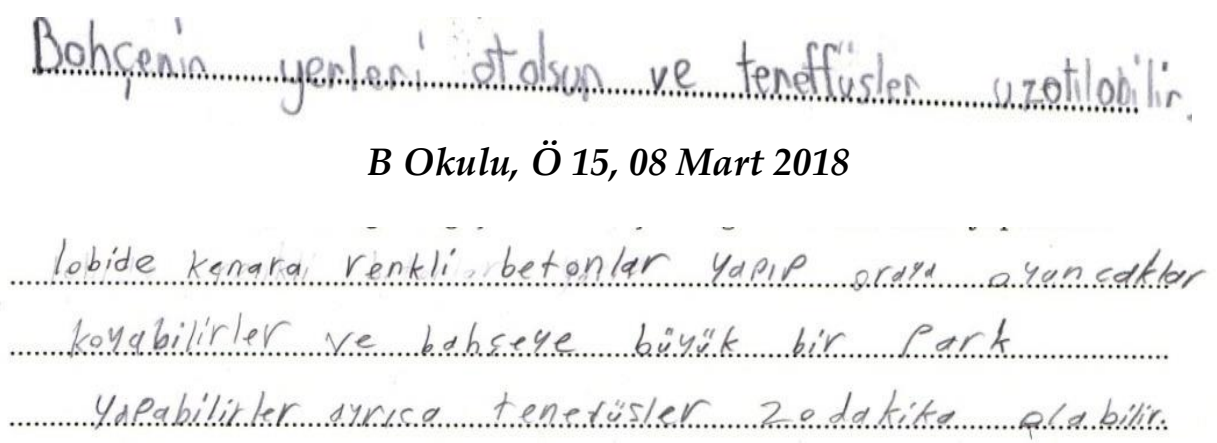

C Okulu Ö 29, 09 Mart 2018

TEMA IV: Öğretmenlerin daha etkili ve verimli teneffüsler geçirilmesine yönelik fikirleri nelerdir?

Öğrencilerin teneffüslerde en fazla zamanı geçirdikleri alanın okul bahçesi olduğu düşünülerek öğretmenlerden görev yaptıkları okulun bahçesine yönelik görüşleri alınması uygun görülmüştür. Bu doğrultuda öğretmenlere yönelik olarak hazırlanan formun birinci 
bölümünde yer alan okulun fiziki yapısına yönelik görüşleri, ikinci bölümde ise teneffüslerin daha etkili ve verimli geçirilmesine yönelik görüşleri alınmıştır. Bu bağlamda öğretmenlerin gözünden 3 farklı uygulama okulundaki fiziki alt yapı Tablo 4'de yer almaktadır.

Tablo 4. Uygulama okullarının fiziki yapısı

\begin{tabular}{lccc} 
Özellikler & A Okulu & B Okulu & C Okulu \\
\hline Okul bahçesini çevreleyen duvarlar var mı? & $\sqrt{ }$ & $\sqrt{ }$ & $\sqrt{ }$ \\
Tören alanı & $\sqrt{ }$ & & $\sqrt{ }$ \\
Basketbol sahası & $\sqrt{ }$ & $\sqrt{ }$ & $\sqrt{ }$ \\
Voleybol sahası & $\sqrt{ }$ & & $\sqrt{ }$ \\
Bahçe zemini & Asfalt/Beton & Asfalt/Beton & Yeşil Alan/Beton \\
Farklı aktiviteler yapılacak alanlar & $\sqrt{ }$ & & $\sqrt{ }$ \\
Farklı teneffüs politikası & & & $\sqrt{ }$ \\
\hline
\end{tabular}

Tablo 4 incelendiğinde üç okulun da birbirine benzer ve farklı yönleri olduğu görülmektedir. Bu özelliklerin hali hazırdaki birçok ilkokulun bahçesine yönelik standart özellikleri yansıttığı söylenebilir. Bu yapıdaki okullarda öğretmenlik yapan öğretmenlerin teneffüslere yönelik değerlendirmeleri için yapılan analiz sonucunda elde edilen temalar ise Tablo 5'de yer almaktadir.

Tablo 5. Öğretmenlerin daha etkili ve verimli teneffüsler geçirilmesine yönelik fikirleri

\begin{tabular}{|c|c|c|c|c|c|}
\hline \multirow[t]{2}{*}{ Alt temalar } & \multirow[t]{2}{*}{ Kodlar } & \multirow{2}{*}{$f$} & \multirow{2}{*}{$\%$} & \multicolumn{2}{|c|}{ Toplam } \\
\hline & & & & $f$ & $\%$ \\
\hline \multirow{7}{*}{$\begin{array}{l}\text { Okul bahçesinin } \\
\text { fiziksel olarak } \\
\text { düzenlenmesi }\end{array}$} & Bahçe boyutlarının öğrenci mevcuduna uyumu & 8 & 32 & \multirow{7}{*}{25} & \multirow{7}{*}{52} \\
\hline & Yeşil alanın daha çok olması & 6 & 24 & & \\
\hline & Dinlenme alanları olmalı & 4 & 16 & & \\
\hline & Spor alanların daha fazla olması & 3 & 12 & & \\
\hline & Sallanma ve tırmanma alanları olmalı & 2 & 8 & & \\
\hline & Hava koşullarına uygun hareket alanları olmalı & 1 & 4 & & \\
\hline & Hayvan barınağı olmalı & 1 & 4 & & \\
\hline \multirow{3}{*}{$\begin{array}{c}\text { Içeriksel } \\
\text { düzenlenmesi }\end{array}$} & Teneffüs süreleri daha uzun olmalı & 8 & 50 & \multirow{3}{*}{16} & \multirow{3}{*}{33} \\
\hline & Farklı oyun alanlarının arttırılması & 7 & 44 & & \\
\hline & Eğitici oyun alanları eklenmeli & 1 & 6 & & \\
\hline
\end{tabular}




\begin{tabular}{llrrrrr}
\hline & Güvenlik önlemleri artırılmalı & 4 & 58 & & \\
Öğrenciye Uygunluk & Bahçedeki ses sinıfları etkilememeli & 1 & 14 & 7 & 15 \\
& Çocuk ruhuna uygun bir alan olmalı & 2 & 28 & & \\
\hline & Toplam & 48 & 100 & 48 & 100
\end{tabular}

Tablo 5 incelendiğinde öğretmenlerin verdikleri cevaplar incelendiğinde okul bahçesinin fiziksel olarak düzenlenmesi, içeriksel düzenlemesi ve öğrenciye uygunluk alt temaları altında toplandığı görülmektedir. Çoğunlukla bahçe boyutlarının öğrenci sayısı ile uyumlu olması, spor alanlarının arttırılması ve farklı oyun alanlarının fazla olması görüşünü tekrarladıkları görülmektedir. Ayrıca sallanma ve tırmanma alanı, hayvan barınağı ve çocuk ruhuna uygun ortamların olması gibi görüşler de ifade edilmiştir. Öğretmen cevaplarından bazıları şöyledir:

Okul bahcemiz genis bir alas degat. Gocukbor in oynayabilecegi biskac oyun aloni (sekuek, hedef..) var fakat yeterli

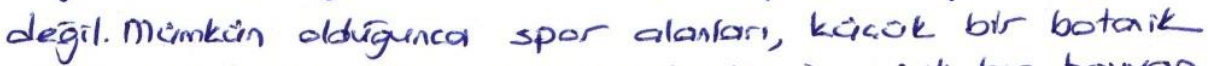
bahse (kendi ektikjerini yetistirebrlecekleri), minik bor hayvan barinogr ve egitici oyun alanbar cok faydall olacaktir. (:)

\section{A Okulu, ÖĞRT 2, 06 Mart 2018}

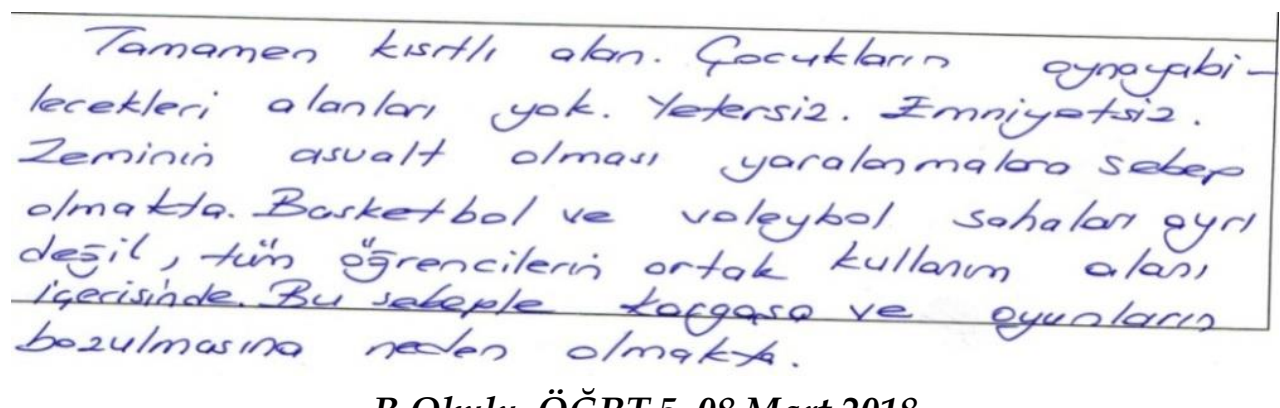

B Okulu, ÖĞRT 5, 08 Mart 2018

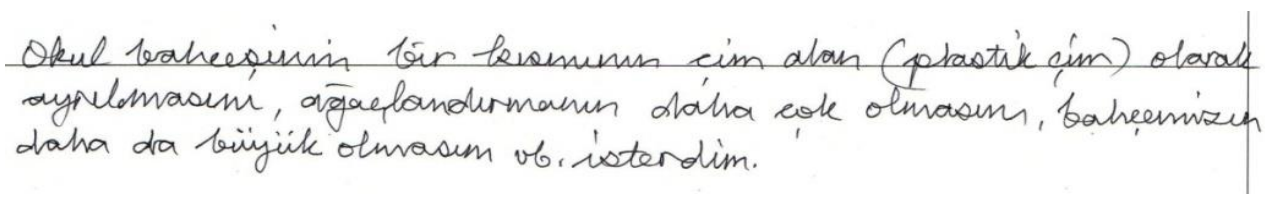

\section{Okulu, ÖĞRT 2, 09 Mart 2018-03-20}

Öğretmenlerin verdikleri yanıtlar incelendiğinde öğrencilerin de hayalini kurdukları ve olması gerektiğini düşündükleri fikirlerle örtüştüğü görülmektedir.

\section{Tartışma ve Sonuç}

Öğrencilerin teneffüse yönelik görüşlerini alarak var olan durumu ve öğretmenlerin daha etkili ve verimli teneffüsler geçirilmesine yönelik görüşlerini ortaya koymak amacıyla yapılan bu çalışmada elde edilen sonuçlar şöyledir:

Öğrenciler teneffüste vakitlerini nasıl geçirmektedir? sorusuna ilişkin görüşler incelendiğinde öğrencilerin teneffüslerini çoğunlukla açı alanda oyun oynayarak ve spor yaparak geçirdikleri görülmektedir. Alan yazında da yer alan bir çok çalışmada çocukların açık havaya 
çıkmasının gerekliliği ve önemi üzerinde durulmaktadır (Frost, 2012). Koşma, kocvalamaca aktivitelerinin teneffüs süresince devam ettğini, daha çok geleneksel oyunların (seksek, saklambaç vb) yere çizili alanlarda, duvar köşelerinde ve okul bahçesinde oynandığ1 sonucuna ulaşılan bir başka çalışamada da benzer bir sonuca ulaşıldığ görülmektedir (Karadeniz ve ark., 2018).

Teneffüslerde öğrencileri en çok rahatsız eden durumlar nelerdir? sorusuna ilişkin görüşleri incelendiğinde diğer öğrencilerin kendilerine çarpması/itmesinden rahatsız oldukları, teneffüs sürelerinin yetersizliği ve çok gürültü olması olarak ifade edilmiştir. Bu duruma en çok okul mevcutları ile okul bahçesinin büyüklügü ve niteliğinin uyumsuz olmaları sebep olarak gösterilebilir. Bu duruma çare olarak farklı teneffüs politikaları uygulanabilir; teneffüse zilsiz çıkma ve her sınıf düzeyinde ayrı saatlerde bahçeyi kullanma veya teneffüs alanlarında sınıf düzeyine göre çeşitlilik sağlama vb. Böylece çocukların kendilerine ait alanlara sahip olması sağlanabilir. Bu konuda yapılan çalışmalarda okul ortamlarındaki gürültünün normal ses aralığının üstünde olduğu ve yoğunlukla okul koridorlarında olduğu sonucuna ulaşılmıştır (Özbıçakçı ve ark., 2012). Bu bağlamda okul bahçesine çıkmaya yönelndirilmesi ile gürültünün atkisinin azaltılması sağlanabilir.

Öğrencilerin hayallerindeki teneffüslere yönelik fikirleri nelerdir? sorusuna ilişkin görüşleri incelendiğinde hayallerindeki teneffüslere yönelik olarak ise en çok vurguladıkları isteklerin oyun alanlarının fiziksel olarak düzenlenmesi ve zamansal düzenlemeleri içerdiği görülmektedir. Çoğunlukla okul bahçesinde park, spor alanı ve farklı oyunlar için uygun alanlarının olması ve teneffüslerin sürelerinin uzatılması gerektiği ifade edilmiştir. Teneffüs süreleri ile ilgili yapılan çalışmalar da göstermektedir ki etkili ve kaliteli teneffüsler öğrenme ortamını ve sınıf iklimini olumlu etkilemektedir (Yaman, 2006; Kıncal ve Genç, 2002; Hotaman ve Yüksel Şahin, 2009). Süresi kısalan teneffüsler, temel ihtiyaçların başında gelen beslenmenin yanı sıra diğer ihtiyaçları giderme, oyun oynama ve sosyalleşme olanaklarını da kısıtlamaktadır (Sarışık ve Düşkün, 2016). Bu yüzden teneffüs sürelerinin özellikle ilkokul dönemindeki öğrenciler için uzaltılması gerektiği söylenebilir.

Öğretmenlerin daha etkili ve verimli teneffüsler geçirilmesine yönelik fikirleri nelerdir? sorusuna ilişkin görüşleri incelendiğinde daha etkili ve nitelikli teneffüsler icin okulun fiziki yapısına ilişkin görüşlerin ağırlık kazandığı bahçe boyutlarının öğrenci sayısı ile uyumlu olması, farklı oyunlar oynayabilecekleri alanların fazla olması görüşünü tekrarladıkları görülmektedir. Bu bağlamda öğrencilerin öğretmenlerin ortak bir görüşe sahip oldukları söylenebilir. Ayrıca sallanma ve tırmanma alanlarının, hayvan barınağının olması ve çocuk ruhuna uygun olması gerektiği görüşleri de ifade edilmiştir. Öğretmen, müdür ve teneffüs koçu görüşme notlarına, öğrenci odak grup görüşmelerine, gözlem notlarına ve öğretmenlere uygulanan anket sonuçlarına bakıldığında öğrencilerin daha kaliteli ve amaçlı zaman geçirdikleri görülmektedir.

Playworks okullarında yürütülen (2012) her çocuğa güvenli bir ortamda eğlenceli zaman geçirme ve oyuna katılma fırsatı vermesi gerekçesi ile teneffüslere odaklanıyor. Yine bu çalışmada Playworks okullarında da teneffüslerin etkililiği ile zorbalığın anlamlı bir şekilde azaldığı sonucuna ulaşılmıştır. Bu çalışmada ilk ders zili çalmadan önce başlayan ve okul günü bittikten sonra da devam eden, Playworks'ün görevlendirdiği eğitmenler mahallelerde yaşça büyük çocukların üstlendiklerine benzer roller üstlenmektedir. (Okullarda Empatiyi 
Geliştirmek İçin Bir Rehber, 2012). Böylece günümüz dünyasında sıkça duyduğumuz fiziksel ve duygusal zorbalığın azalması sağlanabilir.

Bütün bu sonuçlar ışı̆̆ında öneriler şu şekilde sunulabilir.

Araştırmacılara yönelik olarak;

a. Okuldaki eğitim ve öğretim ortamının önemli bileşenlerinden biri olan teneffüsler ile ilgili daha fazla çalışma yapılabilir.

b. Farklı uzmanların bir araya gelerek oluşturacağı standartlara uygun fiziki ortamları oluşturulabilir.

c. Dünyadaki uygulama örnekleri incelenebilir.

d. Sadece öğretmen ve öğrencilerin değil, okulda görev yapan eğitim yöneticilerinin veya velilerin görüşleri alınarak da var olan durumu daha geniş bir bakış açısıyla ortaya koyan başka çalışmalar da yapılabilir.

Uygulayıcılara yönelik olarak ise;

a. Ülkemizdeki uygulamalarda zamansal ve içeriksel bir takım düzenlemeler yapılması önerilebilir.

b. Teneffüslerdeki gürültünün azaltılmasına yönelik olarak gürültünün daha az etkili olması içinde öğrencilerin olabildiğince açı havada vakit geçirmeleri sağlanabilir.

\section{Teşekkür ve Bilgilendirme}

Bu çalışma 27-29 Nisan 2018 tarihinde Budapeşte/ Macaristan'da yapılan IV. Uluslararası Afro Avrasya Araştırmaları Kongresi'nde sözlü bildiri olarak sunulmuştur.

\section{Kaynakça}

Berg, B. L. (2001). Qualitative research methods for the social sciences (4th ed.). Allyn ve Bacon, Needham Heights, MA.

Blatchford, P. \& Sumpner, C. (1998). “What do we know about breaktime? Results from a national survey of breaktime and lunchtime in primary and secondary schools", British Educational Research Journal, 24(1), 79-94.

Brez, C. \& Sheets, V. (2017). "Classroom benefits of recess", Learning Environments Research, 20(3), 433-445.

Bulunuz, M., Bulunuz, N., Tavşanlı, Ö. F., Orbak, A. Y., \& Mutlu, N. (2018). İlkokullarda gürültü kirliliğinin düzeyi, etkileri ve kontrol edilmesine yönelik sınıf öğretmenlerinin görüşlerinin değerlendirilmesi. Kastamonu Ĕ̆itim Dergisi, 26(3), 661-671.

Bumin, G. (2018). ,“Günümüz Toplumunda Çocukların Çevresi, Rolleri ve Aktiviteleri“, (ed.) Gonca Bumin, Çocuklarda Ergoterapi, Ankara: Hipokrat Yayınevi.

Davey, L. (2009). "The Application of Case Study Evaluations", Elementary Education Online, 8(2), $1-3$.

Frost, J. L. (2012). "The changing culture of play“, International Journal of Play, 1(2), 117-130.

Golinkoff, R. M., Hirsh-Pasek, K. \& Singer, D. G. (2006). “Why play = learning: A challenge for parents and educators". (ed.) Dorothy G. Singer, Roberta Michnick Golinkoff, Kathy HirshPasek Play = learning: How play motivates and enhances children's cognitive and social-emotional growth, New York: Oxford University Press. 
Hotaman, D., \& Yüksel Şahin, F. (2009). “Okulun öğelerine ve bazı değişkenlere göre ilköğretim öğrencilerinin saldırganlık düzeylerinin incelenmesi", E-Journal of New World Sciences Academy (NWSA), 4(3), 833-858.

Karadeniz, B., Özyavuz, A., Türk, Y. A., Topaloğlu, G., \& Bayram, Z. Y. (2018). "İlkokul Bahçelerinde Davranış Haritaları Bağlamında Mekânsal ve İşlevsel Bir Analiz: Trabzon Örneği. Journal of History Culture and Art Research, 7(3), 649-667.

Karasel Ayda, N., \& Güneyli, A. (2018). "Recess" in the Eyes of Primary School Students: Cyprus Case“. Sustainability, 10(2), 355-375.

Kincal, R. \& Genç, S. (2002). “İlköğretimde Teneffüsün Yeri ve Önemi“" Eğitim Araştırmaları Dergisi, 9, 86-94.

London, R. A., Westrich, L., Stokes-Guinan, K., \& Mclaughlin, M. (2015). "Playing Fair: The Contribution of High-Functioning Recess to Overall School Climate in Low-Income Elementary Schools“, Journal of school health, 85(1), 53-60.

Miles, M. B. \& HubermaN, A. M. (1994). Qualitative data analsis: An expanded source book.-USA: Sage Publication.

Okullarda Empatiyi Geliştirmek İçin Bir Rehber (2012), http://www.farkyaratansiniflar.org/pdf/Empati-icin-rehber.pdf web adresinden 15.03.2018`de alınmıştır.

Özbiçakçi, F. Ş., Çapik, C., Gördes, N., Ersin, F., \& Kissal, A. (2012). “Bir okul toplumunda gürültü düzeyi tanılaması ve duyarlılık eğitimi“", Eğitim ve Bilim, 37(165), 238-245.

Patton, M. Q. (1997). How to use qualitative methods in evaluation. Newbury Park: Sage Publication,

Pellegrini, A. D., \& Davis, P. D. (1993). “Relations between children's playground and classroom behaviour", British journal of educational psychology, 63(1), 88-97.

Ramstetter, C. L., Murray, R., \& Garner, A. S. (2010). "The crucial role of recess". Journal of School Health, 80, 517-526

Rhea, D. J. (2016). “Recess: The forgotten classroom", Instructional Leader Journal, 29(1), 2-6.

Sariişik, Y. \& Düşkün, Y. (2016). Çocukların Gözünden Okulda Yaşam. Eğitim Reformu Girişimi, Istanbul.

Stapp, A. C., \& Karr, J. K. (2018). “Effect of Recess on Fifth Grade Students' Time On-task in an Elementary Classroom“, International Electronic Journal of Elementary Education, 10(4), 449-456.

Tamer, N., Küçükçiftçi, S., ve Şan, B. (2011). İlköğretim okullarında gürültüden rahatsızlığın alan çalışmalarına bağlı olarak saptanması, İTÜ Dergisi, 10(2), 169-181.

Tekeci, Y. (2018). "Çocukların Okulda Fiziksel Aktivitelere Katılımı", (ed.) Gonca Bumin, Çocuklarda Ergoterapi, Ankara: Hipokrat Yayınevi.

Yaman, E. (2006). "Eğitim sistemindeki sorunlardan bir boyut: Büyük sınıflar ve sınıf yönetimi", Gazi Üniversitesi Türk Eğitim Bilimleri Dergisi, 4(3), 261-274.

Yıldırım, A., \& Şimşek, H. (2008). Nitel araştırma yöntemleri, Ankara: Seçkin Yayıncılık.

Yin, R. K. (2003). Case study research. Design and methods. Thousand Oaks: Sage Publication.

Zask, A., Van Beurden, E., Barnett, L., Brooks, L. O., \& Dietrich, U. C. (2001). “Active school playgrounds-myth or reality? Results of the "move it groove it" project", Preventive medicine, 33(5), 402-408. 